\title{
A Case Study on the Problems and Suggestions in Foreign Language Teaching and Learning at Higher Education
}

\author{
Menderes Unal ${ }^{1}$, Elif Ilhan ${ }^{2}$ \\ ${ }^{1}$ School of Education, Ahi Evran University, Kirsehir, Turkey \\ ${ }^{2}$ School of Foreign Languages, Ahi Evran University, Kirsehir, Turkey \\ Correspondence: Menderes Unal, School of Education, Ahi Evran University, Kirsehir, Turkey, Terme Srt. 40100, \\ Turkey.
}

Received: March 27, 2017

doi:10.11114/jets.v5i6.2302
Accepted: April 24, $2017 \quad$ Online Published: April 27, 2017

URL: https://doi.org/10.11114/jets.v5i6.2302

\begin{abstract}
This study explores and identifies some reasons for the problems of foreign language learning (English) and teaching from the perspective of instructors and learners using the case study model. The data of the study was gathered by a semi-structured interview form, and the study group of the research was composed of English language instructors and graduate students at Ahi Evran University. Random sampling method was used to determine 15 instructors and 20 graduate students to face-to-face interview, and the data of the study was analysed by content analysis method, which the students and instructors agreed on students who have been problematic in language learning process. In addition to students, examination systems, instructional programs, language teachers' qualifications and learning environments have been considered as barriers to language learning. On the other hand, students and instructors suggested starting learning/teaching English earlier, much more practice and exams on all four skills; elective courses; more practice and communication; revisions in teacher training system, considering individual differences; motivating and encouraging students; and designing well equipped language environment and teaching materials.
\end{abstract}

Keywords: higher education, problems and solutions, foreign language, teaching, learning

\section{Introduction}

Educational systems have the responsibility to train individuals to actively participate in political, economic and social relations. For active participation, one of the needs of individuals, because it is not their first language, is to develop skills in listening, speaking, reading and writing in foreign languages, especially in English accepted as lingua franca, so they can communicate, make projects, gather data, and make businesses in international platforms. Since it is impossible to be an active participant of global life without proficiency in English, English is regarded as not a foreign language to be learnt, but as an important qualification everyone should obtain (Wolff, 2003).

The importance of getting proficiency in English has been emphasized in numerous academic papers and reports around the world. Society and governments have also made efforts and investments devoted to improving skills in English, but there are various difficulties, challenges and on-going problems preventing them to develop solutions to produce outcomes that do not meet expectations.

Teaching/learning English as a foreign language is a challenging task in developing countries in general and particularly in Turkey. To fulfill that task in the Turkish education system, compulsory English courses have been introduced beginning from the second grade of primary education, which was described by Johnstone (2009) as "possibly the world's biggest widespread introduction of languages in primary schools has gest policy development in education" and continuing till the end of higher education.

Students taking English courses, especially in state schools, for such a long time are not gaining the necessary skills at the targeted levels in reading, listening, writing and speaking (Oktay, 2015). It is a common belief that our education system is not successful in teaching English (Tosun, 2012). That belief has been corroborated by the results of several academic papers (Aktas, 2005; Bayraktaroglu, 2012; Enginarlar, 2003; Daranc1k, 2008; Gunes, 2011; Hamamc1, 2013; Isık, 2008; Kocaman, 1983; Koru and Akesson, 2011; Oguz, 1999; Paker, 2007; Sahin, 2009; TEPAV, 2014; Tilfarlıglu and Ozturk, 2007; YOK, 2007). The problem indicated in the above-cited studies can be categorized into four groups, 
namely, problems about the education system, about the educational process, about teachers and about learners in that study.

\subsection{Problems about Education System}

Teaching English is always a challenging task and that task requires nationwide efforts; thus, it is vital to have a national system of foreign language teaching (Oktay, 2015), which requires a scientific plan. Despite the important developments in educational systems such as increasing the number of English courses, starting English courses at earlier grades, they hardly produce the expected results if there is a lack of scientific planning, as Isik (2008) stated for the Turkish educational system.

Another important drawback to completing that task is student achievement testing system, which is a significant step to get promoted in higher education context. Because of that testing system, although there are some steps taken in terms of government policies that typically advocate teaching communicatively $(\mathrm{Li}, 1998)$, they are often incompatible with real expectations and practices in the learning environment, which often focuses on grammar and vocabulary. On the one hand, as Kunnan (2005) noted, there is a tendency to "'teach to the test' with less time devoted to activities that are not part of the test". This backwash/wash-back effect has negative impacts in higher education context similar to other education contexts.

\subsection{Problems about Educational Process}

To enable learners to acquire intended level of English, educational processes have great importance. It is the curriculum which directs all educational process. The importance of curriculum is so well understood that there is a tendency to make changes in curricula to obtain intended results in advocating teaching effectively, but these changes typically are often incompatible with the demands of national examinations $(\mathrm{Li}, 1998)$ which often focus on grammar and vocabulary. As Kunnan (2005) has noted, it results in the tendency to "teach to the test with less time devoted to activities that are not part of the test" which has negative impacts on educational process.

Moreover, the method of instruction is always a discussion subject in foreign language teaching literature, but there is not a best implementation method. Although teachers may learn to implement traditional methods that mostly to focus on teaching grammar and restrict their teaching in course books (Gomleksiz and Elald1, 2011) and receive only basic training in the underpinning theory and practical applications (Butler, 2005), they are expected to develop themselves to implement different teaching methods.

Another issue in the educational process is the learning places. The atmosphere, appearance, size and equipment of learning places have importance in the learning process. In many parts of the world, large classes are a common challenge (Ho, 2003; Shamim, 2012; Wedgwood, 2007), causing failure in language learning process; because it makes impossible to closely monitor students' language use (Li, 1998) or introduce pair work and group work (Hoque, 2009). It also presents the problem of control and discipline (Butler, 2005).

\subsection{Problems about Teachers}

It is the teacher who is mainly responsible for implementation of the educational process. Unless there are well qualified English language teachers, no amount of investment in education can improve the quality of English education. To Geringer (2003), teacher quality outweighs other factors such as motivation, funding, and class sizes, and qualified teachers can create the best environment for learning. There should be qualified teachers with the ability to teach to obtain quality education, which is an important problem for many developing countries (Paker, 2006).

A potential challenge for teachers concerns with the level of English they require. They need to constantly update their knowledge and equip themselves with the advancements in society and the use of technology in general and in the educational environment (Khan, 2005). On the other hand, foreign language teachers' low proficiency levels or their lack of confidence in their ability is consistently identified in the literature (Ahn, 2011; Ghatage, 2009; Kuchah, 2009).

The reasons for that situation can be understood by the analysis made by Demircan (1988) and about twenty years later by Celebi (2006). They indicated that the sources of English language teachers in Turkey have varied. In addition, some of them have graduated from other faculties than educational faculties, which causes pedagogical problems in education process.

The problems related to teachers seem to be solved with the help of pre- and in-service training, but as Tutunis (2012) stated, there are problems related to the quality of the training systems. For instance, one of the problems in pre-service training is related to quality of curriculum which has been developed without field study and with only expert opinion. A similar problem faced regarding in-service training is that it has been planned by a group of foreign experts, which this problem continues to be implemented (Is1k, 2008). 


\subsection{Problems regarding Learners}

In many language learning contexts, learners may struggle to understand the relevance of learning English, as they have little contact with speakers of the language ( $\mathrm{Ho}, 2003$; $\mathrm{Li}, 1998)$, which causes negative attitudes towards foreign language learning.

One problem on the side of learners is that they are not aware of the importance of proficiency in English; they focus only on passing classes/getting high marks instead of acquiring English. Another problem is that they need help from their parents/tutors in learning a foreign language, but in developing countries such as Turkey, because parents do not have expertise in English, it becomes impossible for them to support their children (Isık, 2008; Paker, 2007; TEPAV, 2014).

The previous explanations show that there are various reasons why most learners have difficulty in learning English. After explaining the reasons for the problem, it is vital to present possible solutions for the problem. In the literature, there are some studies that focus on the ways of solving the mentioned problem. The possible solutions are establishing a coordination committee for the language learning problem, designing a new curriculum, revising syllabuses, organizing in-service training, increasing the number of courses, and changing the teacher training systems (Bayraktaroglu, 2012; Enginarlar, 2003).

The key challenges and the solutions identified in the literature show that the studies trying to explain that issue have been mostly focused on teaching English in pre-higher education levels and performed with teachers of English, young learners and their parents (Kocaman, 1983; Koru and Akesson, 2011; Tilfarlioglu and Ozturk, 2007). Consequently, the learners and teachers of English at higher education context have been overlooked. However, the almost over 1 billion learners of English are not a homogeneous or static group but a diverse and dynamic one in terms of age, gender, nationality, jobs, and aims. For that reason, all the target groups should be interviewed so that more general determinations and suggestions can be made. The experts who study the issue at higher education level, the instructors who can make controversial analysis about foreign language teaching and graduate students should be included such studies to represent the target group holistically and the cumulative results of that teaching process in higher education context.

The study aims to determine the on-going problems regarding foreign language teaching in higher education context and to present practical suggestions to break the foreign language barriers by analyzing the suggestions made by the experienced individuals on that issue.

\section{Method}

This research was constructed as a descriptive study, describing events, objects, circumstances, institutions, groups and various areas as what they are (Kaptan, 1998). One of the qualitative research methods, case study, was preferred to reveal perceptions and cases in their natural environment as exact and integrated (Yildırım and Simsek, 2008). The study group of the research was composed of English language instructors and graduate students at Ahi Evran University. The random sampling method was used, and 15 instructors and 20 graduate students were interviewed.

\subsection{Data Collecting}

Because it is aimed to study the instructors and students' inner world and understand their perspectives regarding problems in language teaching process (Patton, 2002), a semi-constructed interview form was used to collect data. The form included questions regarding personal information and two open-ended questions about problems they have experienced or observed during their language learning process and their suggestions for each problem they stated.

\subsection{Data Analyzing}

Collected data was analysed using the content analysis approach, which is one of the qualitative research data analysis techniques. In the qualitative data analysis process, first, data from document analysis and interviews were transferred to computer. Texts were examined in detail and categories and terms were then determined. Then, data was separated to meaningful parts and we tried to determine the conceptual meanings of each part. Parts with a meaningful whole were coded. After finding common codes, categories were determined. There existed two themes (opinions about problems and suggestions) and six categories (education system, instructional program, teachers, teaching materials, students' characteristics and learning environments). Codes in categories were commented in relation with each other, and results were interpreted based on the study's aim and supported with participants' opinions via direct quotations.

\subsection{Reliability and Validity}

In quantitative researches, reliability and validity are issues of special interest. First, to improve the validity and the reliability of the research, the research process was explained in detail, starting from the preparation of data collection tool to the application and analysis steps Second, research results were shared with individuals participating to the 
research, and they were asked to comment on these results. Third, raw data was presented to another researcher specializing in this field, and the researcher was asked to establish themes and coded opinions. This process confirmed that the contents prepared by the researchers and experts were very similar. Thus, the results were confirmed. In establishing the inter-rater reliability rate, a specialist at the faculty was asked to sort the opinions into the six categories, and the level of agreement between the colleague and the researchers was $90 \%$. The colleague placed 19 concepts under categories different from that of the researcher. In other words, Reliability =Agreement /Agreement + Disagreement X $100=171 / 171+19 \times 100=90 \%$. Fourth, direct quotations were used to analyze opinions of participants. Fifth, the entire research process was explained in details. Finally, the results were compared with other studies of this field (Miles and Huberman, 1994; Yıldırım and Simsek, 2008).

\section{Findings}

Based on the sub-problems of the study, instructors and students views on problems in foreign language learning process were analyzed and presented as follows.

\subsection{Students and Instructors' Views on Problems in Foreign Language Learning Process}

Table 1. Students and Instructors' Views on Problems in Foreign Language Learning Process

\begin{tabular}{llllllll}
\hline Subjects & $\begin{array}{l}\text { Education } \\
\text { System }\end{array}$ & $\begin{array}{l}\text { Instructional } \\
\text { Program }\end{array}$ & Teachers & $\begin{array}{l}\text { Teaching } \\
\text { Materials }\end{array}$ & $\begin{array}{l}\text { Students' } \\
\text { Characteristics }\end{array}$ & $\begin{array}{l}\text { Learning } \\
\text { Environment }\end{array}$ & Total \\
\hline Students & 11 & 26 & 8 & 8 & 34 & 13 & 100 \\
Instructors & 9 & 13 & 11 & 8 & 19 & 12 & 71 \\
Total & 20 & 39 & 19 & 16 & 53 & 25 & 171 \\
\hline
\end{tabular}

Table 1 shows the first theme and students and instructors' views on problems in foreign language learning process, includes six categories. When the-categories are examined, the "Students' characteristics" category has the highest number of concepts ( $\mathrm{f}=53$ ), but the "teaching materials" ( $\mathrm{f}=16$ ) category has the least number of concepts. In other words, students' attitude, behavior and other characteristics were assumed as the main problem in foreign language teaching and learning process. On the other hand, teaching materials for both students and teachers were believed to not cause any additional problems.

Table 2. The Concepts Stated by Students and Instructors under the "Education System" Category

\begin{tabular}{lll}
\hline & Concepts Stated by Students (f=11) & Concepts Stated by Instructors (f=9) \\
\hline Education & Exams (5), beginning learning process late & Educational policy which is unsystematic and not directed for \\
System & (3), quality of education (2), inadequacy & need (3), begin age for learning a foreign language (1), course \\
& of the number of foreign language courses & hours (1), being a compulsory course (2), exams (1), class \\
& (1) & passing system (1)
\end{tabular}

Table 2 shows that students indicated the examination system as the most important problem under the "Education System" Category. A student, [SMD12-M], indicated that "studying focusing on exams like YDS (a national exam- one of the prerequisites to be an academician in Turkey)" is a problem in foreign language learning process. On the other hand, instructors regarded the educational system, which is not directed for students' needs, as the most significant problem. An instructor, [INS8-M], explained that problem as follows, "the state does not have a language education policy which is unsystematic and not directed for need".

Table 3. The Concepts Stated by Students and Instructors under the "Instructional Program" Category

\begin{tabular}{lll}
\hline & Concepts Stated by Students (f=29) & Concepts Stated by Instructors (f=13) \\
\hline Instructional & Not focusing on all language skills (12), lack of & $\begin{array}{l}\text { Lack of quality (4), lack of practice (3), } \\
\text { Program }\end{array}$ \\
practice-application (6), rote approach (4), method (3), & $\begin{array}{l}\text { method (3), same beginning level in every } \\
\text { proaram (1), heavy content (1), problems in }\end{array}$ \\
\hline
\end{tabular}

Table 3 shows that students thought the instructional program did not focus on language skills and lacked practical application. Similarly, instructors focused on lack of quality and practice while explaining the reasons for failure in foreign language learning process. A student, $[S P h D 2-F]$, uttered the following, "It gives utmost importance to English grammar" and an instructor, [INS7-M], said that "courses focusing on grammar-translation" emphasized the practice problem during the language teaching process.

Table 4. The Concepts Stated by Students and Instructors under the "Teachers" Category

\begin{tabular}{lll}
\hline & Concepts Stated by Students (f=8) & Concepts Stated by Instructors (f=11) \\
\hline Teachers & teachers' quality (4), teachers who are not field & teachers who are not field experts (4), not involving students \\
& $\begin{array}{l}\text { experts (2), insufficient number of teachers (1), } \\
\text { problems in teacher training process (1) }\end{array}$ & $\begin{array}{l}\text { in courses (3), not qualified teachers (3), teachers not living } \\
\text { in an environment which target language is used (1) }\end{array}$ \\
\hline
\end{tabular}

Table 4 shows that students claimed that teachers were not experts in the field and lacked qualification, creating problems. A student, [SPhD8-F] focused on teachers' qualification, expressing "insufficiency of individuals who teach 
foreign language". In a similar way, [INS8-M] explained, "there aren't talented and sufficient foreign language instructors at schools".

Table 5. The Concepts Stated by Students and Instructors under the "Materials" Category

\begin{tabular}{lll}
\hline & Concepts Stated by Students ( $\mathrm{f}=8)$ & Concepts Stated by Instructors ( $\mathrm{f}=8)$ \\
\hline Materials & $\begin{array}{l}\text { Lack of materials (5), stereotyped materials (1), } \\
\text { quality of materials (2) }\end{array}$ & $\begin{array}{l}\text { Quality of course books (5), high prices of foreign } \\
\text { materials (1), quantity of materials (1) }\end{array}$ \\
\hline
\end{tabular}

Table 5 depicts there are problems related to the materials in terms of quality and quantity as emphasized by students and instructors. Student [SPhD4-M] criticized materials by stating "The materials are stereotyped (always the same)". However, instructor [INS5-M] focused on the quality of national materials in foreign language expressing "National materials are not good enough; besides, they are too expensive".

Table 6. The Concepts under the "Students' Characteristics" Category

\begin{tabular}{lll}
\hline & Concepts Stated by Students ( $\mathrm{f}=34)$ & Concepts Stated by Instructors (f=19) \\
\hline Students' & Resistance/ prejudice toward language learning & not being aware of its importance (5), lack of \\
Characteristics & (6), lack of motivation (6), not being aware of & motivation (5), cultural resistance (3), readiness (2), \\
& importance (5), difficulty (3), study habits (5), & $\begin{array}{l}\text { lack of family support (1), anxiety, fear of being } \\
\text { unsuccessful (1), learned helplessness (1), not patient } \\
\text { memory problems (2), age excuse (1) }\end{array}$
\end{tabular}

Table 6 shows that there are problems related to the students' characteristics in the foreign language learning process. Both students and instructors specified resistance, lack of motivation and not being aware of its importance. A student, [SPhD1-M] focused on motivation by stating "in case of mispronunciation, kidding colleagues lead lack of motivation". Similarly, instructor [INS7-M] expressed the importance of awareness by stating the following, "Some students have resistance towards a foreign language because of differences in culture. Besides, they think language learning is a waste of time and useless for future. So they fail".

Table 7. The Concepts under the "Learning Environment" Category

\begin{tabular}{lll}
\hline & Concepts Stated by Students ( $\mathrm{f}=13)$ & Concepts Stated by Instructors (f=12) \\
\hline Learning & Turkish-speaking environment (5), inadequacy of & $\begin{array}{l}\text { Inadequacy of learning environment (6), } \\
\text { Environment }\end{array}$ \\
& $\begin{array}{l}\text { learning environment (5), inefficient courses (2), } \\
\text { expensive courses (1) }\end{array}$ & $\begin{array}{l}\text { Turkish-speaking environment (3), class synergy } \\
(1), \text { not homogeny classroom (2) }\end{array}$ \\
\hline
\end{tabular}

Table 7 shows that students and instructors focused on the inadequacy of learning environment with the expressions; "inadequacy of physical conditions-lack of language laboratories" by [SPhD2-F] and "unsuitability of learning environment" by [INSIO-F].

\subsection{Students' and Instructors' Suggestions for the Problems in Foreign Language Learning Process}

Table 8. Students' and Instructors' Suggestions for the Solution of Problems

\begin{tabular}{llllllll}
\hline Subjects & $\begin{array}{l}\text { Education } \\
\text { System }\end{array}$ & $\begin{array}{l}\text { Instructional } \\
\text { Program }\end{array}$ & Teachers & $\begin{array}{l}\text { Teaching } \\
\text { Materials }\end{array}$ & $\begin{array}{l}\text { Students' } \\
\text { Characteristics }\end{array}$ & $\begin{array}{l}\text { Learning } \\
\text { Environment }\end{array}$ & $\begin{array}{c}\text { Total } \\
\text { Students }\end{array}$ \\
22 & 20 & 15 & 15 & 21 & 18 & 111 \\
Instructors & 11 & 18 & 12 & 9 & 12 & 15 & 77 \\
Total & 33 & 38 & 27 & 24 & 33 & 33 & 188 \\
\hline
\end{tabular}

Table 8 shows the Students' and instructors' solution suggestions for the problems in foreign language learning process, and the suggestions center upon "instructional program", "education system", "Students" characteristics" and "learning environment" categories. However, there are limited suggestions regarding teaching materials and teachers. Students think that education system should be developed and tailored for students' expectations supplying particular learning environments. Similarly, teachers suggest that instructional programs should be redesigned considering real life and students' characteristics.

Table 9. The Concepts Suggested by Students and Instructors under the "Education System" Category

\begin{tabular}{|c|c|c|}
\hline & Concepts Stated by Students $(\mathrm{f}=22)$ & Concepts Stated by Instructors $(\mathrm{f}=12)$ \\
\hline $\begin{array}{l}\text { Education } \\
\text { System }\end{array}$ & $\begin{array}{l}\text { To start learning English earlier (5), exams on all four skills } \\
\text { (4), constructed level system (3), increasing class hours (2), } \\
\text { focusing on Vocational English (2), speaking courses outside } \\
\text { classrooms (3), going abroad (2), examining European } \\
\text { educational system (1) }\end{array}$ & $\begin{array}{l}\text { Elective courses (4), qualified educational } \\
\text { policy (3), increasing class hours (2), exams } \\
\text { on all four skills (2), classrooms in which } \\
\text { students have the same level of English (1) }\end{array}$ \\
\hline
\end{tabular}

Table 9 shows that while students indicated to start learning English earlier and exams on all four skills as a solution, instructors indicated elective courses and qualified educational policy. For example, [SPhD1-M] uttered that "It should be encouraged to start learning English at very early ages", on the other hand, an instructor explained that [INS5-M]: 
"Language courses should be elective especially in higher education level where students can take their own decision".

Table 10. Suggested Concepts under the "Instructional Program" Category

\begin{tabular}{lll}
\hline & $\begin{array}{l}\text { Concepts Stated by Students } \\
(\mathrm{f}=16)\end{array}$ & Concepts Stated by Instructors (f=16) \\
\hline Instructional & $\begin{array}{l}\text { Language practice (7), linear } \\
\text { Program (4), focusing on four }\end{array}$ & $\begin{array}{l}\text { Learning by experience (6), using target language (2), linear program (1), } \\
\text { program }\end{array}$ \\
$\begin{array}{l}\text { skills (3), improving evaluation } \\
\text { system (2) }\end{array}$ & $\begin{array}{l}\text { activities (1), organizing program based on students' features (1), not so much } \\
\text { content (1), courses focusing on four skills (1) }\end{array}$ \\
\hline
\end{tabular}

Table 10 shows that both the instructors and students offered language practice to solve problems related to instructional program. As indicated by [SMD19-F]; "Practice opportunity should be enhanced for students" and by [INS6-F]; "Courses should be organized efficiently and be skill-based"

Table 11. The Concepts Suggested by Students and Instructors under the "Teachers" Category

\begin{tabular}{lll}
\hline Concepts Stated by Students ( $\mathrm{f}=16)$ & Concepts Stated by Instructors (f=12) \\
\hline Teachers & $\begin{array}{l}\text { Field expert teachers (6), qualified teachers (5), } \\
\text { native speaker teachers (2), sending future teachers } \\
\text { abroad (2), careful selection of teachers (1) }\end{array}$ & $\begin{array}{l}\text { Qualified teachers (6), self-renewing teachers (3), } \\
(1), \text { sending future teachers abroad (1) }\end{array}$ \\
\hline
\end{tabular}

Table 11 shows that students and instructors emphasized the quality of teachers. For example, student [SPhD20-M] said the following, "Teachers are essential and have a key role in language learning process. Teachers who should have qualified education and good communication" and instructor [INS9-F] stated; "Adequate and efficient teachers should be trained in foreign language teaching".

Table 12. Suggested Concepts under the "Teaching Materials" Category

\begin{tabular}{lll}
\hline & Concepts Stated by Students (f=15) & Concepts Stated by Instructors (f=12) \\
\hline Teaching & Interactive materials (4), audio-visual materials (4), various & Tools for easing communication (3), \\
Materials & $\begin{array}{l}\text { sources (3), materials easy to find (1), reading materials (1), } \\
\text { suitable sources for students' levels (1), increasing quality } \\
\text { levels of course books (1) }\end{array}$ & $\begin{array}{l}\text { book selection (1), new sources (1), domestic } \\
\text { sources (1) }\end{array}$ \\
\hline
\end{tabular}

Table 12 depicts that both instructors and students focused on teaching materials in terms of enabling communication. They also gave importance to improve students' language skills via audio-visual materials. For example, a student, [SMD14-F] expressed the following, "Our books and visual, audio tools should be increased and improved". Similarly, instructor [INS7-M] explained his suggestion by stating the following "It should be needed to be much more careful in selection of course books and visual, audio tools in classrooms should be increased".

Table 13. Suggested Concepts under the "Students' Characteristics" Category

\begin{tabular}{lll}
\hline & Concepts Stated by Students $\quad(\mathrm{f}=20)$ & Concepts Stated by Instructors (f=12) \\
\hline Students' & Loving (7), motivation (6), need (5), exercises to & $\begin{array}{l}\text { Motivation (5), understanding its importance } \\
\text { Characteristics }\end{array}$ \\
& $\begin{array}{l}\text { strengthen memory (1), exercises to decrease } \\
\text { anxiety (1) }\end{array}$ & $\begin{array}{l}\text { (3), feeling of success (3), breaking prejudice } \\
\text { (1) }\end{array}$ \\
\hline
\end{tabular}

Table 13 illustrates that instructors and students thought to solve language learning problems, students should be motivated to get language skills. As a student, [MDS3-F] told the following, "Students should be encouraged and everybody should learn foreign language as they want, not because of a must". On the other hand, an instructor, [INS6-F] suggested, "Preparing learning environments in which students feel the foreign language success, they should be brought in the feelings like. I can do it, I can succeed".

Table 14. Suggested Concepts under the "Learning Environment" Category

\begin{tabular}{lll}
\hline & Concepts Stated by Students $(\mathrm{f}=18)$ & Concepts Stated by Instructors (f=12) \\
\hline Learning & Environments allowing practice (10), going abroad & Language laboratories (5), not crowded \\
Environment & (3), not crowded classrooms (2), efficient courses & classrooms (3), going abroad (2), guest speakers \\
& $(1)$, coordination (1), positive environment (1) & who are native speakers (1), homogenous \\
& & classroom (1)
\end{tabular}

Table 14 shows that students and instructors regarded language environment as a solution to solve problems related to language learning. They focused on classrooms that enable practice such as language laboratories, as [SMD17-M]'s stated, "After students reach a certain level of speaking skill, they should be presented environment where they can do listening and speaking practice" and [INS6-F]'s expressed the following, "Students should get a chance to learn by doing".

\section{Results and Discussions}

Analyzing students and instructors' views on problems in foreign language learning process, "Students' Characteristics", 
category has the highest number of concepts. In other words, both students and instructors agreed on students being problematic in language learning. They specified that students had resistance and lack motivation and self-awareness in the foreign language learning process. That result is similar to many studies which have focused on students' negative attitudes towards foreign language as a problem in implementing successful instructional programs (Aktas, 2005; Bayraktaroglu, 2011; Is1k,2008; Koru and Akesson, 2011; Paker, 2007).

In addition to students' characteristics, examination systems were stated as one of the most important problems by students under the category of "Education System" which instructors regarded not being directed for students' needs. Similarly, a comprehensive study conducted by TEPAV (2011) showed that instructional programs do not show a difference in accordance with students' needs. Students thought that instructional programs did not focus on all language skills and lacked practical application. Similarly, instructors focused on quality of methods and the lack of practice in courses while explaining the reasons for failure in the foreign language learning process. Those finding are in parallel with some studies indicating problems related to the design of teaching process (Paker, 2007). Moreover, students claimed that language teachers were not experts in study field and had problems teaching English. Similarly, instructors emphasized that language teachers were not talented and sufficient in the teaching profession. It was frequently emphasized that most foreign language teachers apply traditional methods and give the excuse of crowded classrooms, and they even have the same speaking and writing problems as students (TEPAV, 2013; Soner, 2007). Similarly, students and teachers thought that schools and classrooms were not well furnished for teaching and that they have been considered as barriers to language learning.

The "Teaching Materials" category, on the other hand, had the least number of concepts in problems during language teaching and learning process. Teaching materials were found to cause no more problems by both teachers and students in language learning.

Students and instructors' suggestions also centered upon "educational system", "instructional program" and "learning environment", and there were very limited suggestions about teaching materials.

Students suggested starting learning/teaching English earlier, much more practice and exams on all four skills as a solution. Instructors indicated elective courses and wanted students to participate courses voluntarily. Similarly, both instructors and students offered language practice to solve problems related to instructional program. In other studies focusing on instructional programs to solve language learning problems, to develop instructional programs giving attention to students' needs was regarded as a prerequisite to dismiss problems faced in foreign language teaching (Celik, 2003; Diken, 2006; Sabuncuoglu, 2010).

Another suggestion was performed on the quality of teachers by emphasizing the importance of teacher training. As Ehrman, Leaver and Oxford (2003) explained, "This in no way excludes good teachers and well- constructed syllabi; in fact, they are even more important than ever for the majority of learners. It is expert teachers with flexible but clear syllabi who can most systematically provide for the individual differences among their students".

Similarly, instructors and students sought to solve problems by motivating students and encouraging learning a foreign language. Ehrman, Leaver, \& Oxford (2003) stated that students need the opportunity to learn in their preferred styles to enable them to learn as much as possible.

Not only students but also instructors regarded well-equipped language environment as a solution for the problems regarding language learning. They focused on classrooms that enable practice like language laboratories.

Instructors and students also focused on teaching materials in terms of enabling communication. They also gave importance to improving students' language skills via audio-visual materials in a similar way with some studies indicating to us audio-visual material as a solution for foreign language learning problems (Enginarlar, 2003; Paker, 2007).

\section{References}

Aktas, T. (2005). Communicative competence in foreign language teaching, Journal of Language and Linguistic Studies, $1(1), 89$.

Bayraktaroglu, S. (2012). Why don't we become successful in foreign language education What should be the trend in foreign language education in Turkey? 1. Yabanc1 Dil Egitimi Calıstayı Bildirileri, 12-13 November 2012. Hacettepe Universitesi, Anakara.

Butler, Y. G. (2005). Comparative perspectives towards communicative activities among elementary school teachers in South Korea, Japan and Taiwan. Language Teaching Research, 9, 423-446. https://doi.org/10.1191/13621688051r176oa

Darancık, Y. (2008). Implementation of alternative methods with literary texts in second language teaching, 
Unpublished Doctorate Thesis. Cukurova University: Adana.

Ehrman, M., Leaver, B., \& Oxford, R. L. (2003). A brief overview of individual differences in second language learning. System by Elsevier Ltd. 31, 313-330. https://doi.org/10.1016/s0346-251x(03)00045-9

Enginarlar, H. (2003). Teaching foreign language in primary schools. Foreign language education and quality search in Turkish education system, İstanbul: Ozel Okullar Dernegi.

Ghatage, M. M. (2009). Introduction of English from Grade 1 in Maharashtra, India. In J. Enever, J. Moon, \& U. Raman (Eds.), Young learner English language policy and implementation: International perspectives (pp. 45-51). Reading, England: Garnet Education.

Gomleksiz, M. N., \& Elald1, S. (2011). Foreign language teaching in the context of constructivist approach. Turkish Studies International Periodical for the Languages, Literature and History of Turkish or Turkic, 6(2), 443-454.

Gunes, F. (2011). Language teaching approaches and practices in Turkish language teaching. Mustafa Kemal Universitesi Sosyal Bilimler Enstitusu Dergisi, 8(15), 123-148.

Hamamc1, Z. (2013). Examination of methodology in foreign language teaching history. Egitim ve Ogretim Arastırmalarl Dergisi, 2(1), 66-70.

Ho, W. K. (2003). English language teaching in Asia today: An overview. In W. K. Ho\& R. Y. L. Wong (Eds.). English language teaching in East Asia today: Changing policies and practices (pp. 1-32). Singapore: Eastern Universities Press.

Hoque, S. (2009). Teaching English in primary schools in Bangladesh: Competencies and achievements. In J. Enever, J. Moon, \& U. Raman (Eds.), Young learner English language policy and implementation: International perspectives (pp. 61-69). Reading, England: Garnet Education.

Isık, A. (2008). Where do wrongs in our foreign language education stem from?. Journal of Language and Linguistics, $4(2), 15-26$.

Johnstone, R. (2009). An early start: What are the key conditions for generalized success? In J. Enever, J. Moon, \& U. Raman (Eds.), Young learner English language policy and implementation: International perspectives (pp. 31-41). Reading, England: Garnet Education.

Kaptan, S. (1998). Scientific research and statistical techniques. Ankara: Bilim Yayınevi.

Kocaman, A. (1983). Foreign language teaching and problems in secondary education institutions. TED BilimselToplantısı. Ankara: SafakMatbaası.

Koru, S., \& Akesson, J. (2011). Turkey's English deficit (Policy Note). Economic policy research foundation of Turkey. Retrieved from http://www.tepav.org.tr/upload/files/1324458212-1.Turkey_s_English_Deficit.pdf, on 20.03.2015.

Kuchah, K. (2009). Early bilingualism in Cameroon: Where politics and education meet. In J. Enever, J. Moon, \& U. Raman (Eds.), Young learner English language policy and implementation: International perspectives(pp. 87-94). Reading, England: Garnet Education.

Kunnan, A. J. (2005). Language assessment from a wider context. In E. Hinkel (Ed.), Handbook of research in second language teaching and learning. Mahwah, NJ: Lawrence Erlbaum.

Li, D. (1998). It's always more difficult than you plan and imagine: Teachers' perceived difficulties in introducing the communicative approach in South Korea. TESOL Quarterly, 32, 677-703. https://doi.org/10.2307/3588000

Miles, M. B., \& Huberman, M. (1994). Qualitative data analysis: An expanded source book. (2nd. Edition). CA: International Education and Professional Publisher, Thousand Oaks, Sage Publications.

Oguz, E. (1999). The Problems of foreign language (English) teaching in elementary schools. Unpublished Master Thesis.Kocaeli University: Kocaeli.

Oktay, A. (2015). Foreign language teaching: A problem in Turkish education. Procedia-Social and Behavioral Sciences, 174, 584-593. https://doi.org/10.1016/j.sbspro.2015.01.587

Paker, T. (2007). Problems of teaching English in schools in Cal Region and suggested solutions. 21. Yuzylla Girerken Gecmisten Gunumuze Cal Yoresi: Cal Yoresi Yardımlasma ve Dayanısma Dernegi Yayını, 3, 684-690.

Sahin, Y. (2009). Factors affecting student achievement negatively in foreign language teaching. Turkiye Sosyal Arastırmalar Dergisi. 13(1), 149-158.

Shamim, F. (2012).Teaching large classes. In A. Burns \& J. C. Richards (Eds.), The Cambridge guide to pedagogy and practice in second language teaching (pp. 95-102). New York, NY: Cambridge University Press. 
TEPAV (2014). Analysis of national needs related to teaching English language in public schools in Turkey. Retrieved from www.tepav.org.tr on 03.09.2015.

Tilfarlioglu, F. Y., \& Ozturk, A. R. (2007). An analysis of ELT teachers' perceptions of some problems concerning the implementation of English language teaching curricula in elementary schools. Journal of Language and Linguistic Studies, 3(1), 202-217.

Tosun, C. (2012). Is it the reason for failure in teaching and learning foreign languages in our country methodology? What should be the trend in foreign language education in Turkey. 1. Yabancı Dil Egitimi Calıstayı Bildirileri, 12-13 Kasim 2012.

Turk Egitim Dernegi (1983). Foreign language teaching and problems in secondary education institutions. Safak Matbaasi: Ankara.

Tutunis, B. (2000). Content- based academic writing, The Internet TESL Journal, 6(7), 1-5.

Wedgwood, R. (2007). Education and poverty reduction in Tanzania. Journal of Educational Development, 27, 383-396. https://doi.org/10.1016/j.ijedudev.2006.10.005

Wolff, D. (2003). Integrating language and content in the language classroom: Are transfer of knowledge and of language ensured? ASp, 41(42), 35-46. https://doi.org/10.4000/asp.1154

Yıldırım, A., \& Simsek, H. (2008). Qualitative research methods in the social sciences, Ankara: SeckinYayınları.

YOK (2007). Higher education strategy of Turkey. Retrieved from http://www.yok.gov.tr/documents/10279/30217/yok_strateji_kitabi/ on 02.08. 2015

\section{Copyrights}

Copyright for this article is retained by the author(s), with first publication rights granted to the journal.

This is an open-access article distributed under the terms and conditions of the Creative Commons Attribution license which permits unrestricted use, distribution, and reproduction in any medium, provided the original work is properly cited. 